\title{
TIPOGRAFÍA Y VERSO LIBRE
}

\author{
Por \\ M V Victoria Utrera TORREMOcha
}

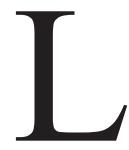

A desarticulación del verso implica la desarticulación de un sistema, de un sistema objetivo, entendido como orden universal aceptado -el ritmo universal de la música de las esferas- y de un sistema subjetivo, entendido como orden interno coherente. La ruptura de la coherencia del sistema conduce al fragmentarismo y afecta al equilibrio universal y al personal. Al desorden que deriva de la ruptura con el orden del verso tradicional corresponde el fragmentarismo visible del verso en el espacio de la página, que se complementa muchas veces con el empleo del encabalgamiento, lo cual supone también un fragmentarismo sintáctico. Así el verso libre desmembrado no sólo va contra el orden rítmico universal representado en el verso tradicional sino contra otro orden de índole racional objetiva que es la sintaxis, aspectos que determinarán en muchos casos una lectura marcada por la incertidumbre.

En "El abandono de la palabra" (1961) y "El silencio y el poeta" (1966)' George Steiner explica que existe un tipo de literatura que entiende que lo inefable está más allá del lenguaje, más allá de las palabras, de ahí la necesidad de derribarlas para conseguir la contemplación absoluta del visionario, la verdad. Ésta no tiene que adecuarse a la lógica racional y lineal que supone la sintaxis. En otros terrenos no artísticos se produce esa misma desconfianza de la palabra, caso de la ciencia o de la filosofía. En la filosofia, por ejemplo, llega un momento en que

\footnotetext{
${ }^{1}$ Véase G. Steiner, "El abandono de la palabra" y "El silencio y el poeta", en Lenguaje y silencio. Ensayos sobre la literatura, el lenguaje y lo inhumano, Barcelona, Gedisa, 1994, pp. 28-55 y 56-78.
} 
se desconfía de la palabra como medio de explicar en mundo, sobre todo a partir del XVII, con Descartes y Spinoza. El lenguaje no sería un camino a la verdad, sino una espiral o una galería de espejos. Sería éste el sentir de la modernidad, como se manifiesta en el Tractatus de Wittgenstein. Así, según dice Steiner, «parece claro que el abandono de la autoridad y el ámbito del código verbal desempeña un papel decisivo en la historia y el carácter del arte moderno». ${ }^{2}$ Es lo que equivaldría al abandono del realismo en pintura y escultura -representación e imitación de la realidad-, paralelo a la época en que el lenguaje es centro de la vida intelectual y sensible. Pero contra esto se rebela el arte moderno: Van Gogh, por ejemplo, no pinta lo que ve, sino lo que siente. Un paso más en esa dirección representa el arte abstracto, de ahí que los títulos de este tipo de obras no apunten a la realidad. Algo equivalente sucede en la música: se rompe la organización musical tradicional, el orden sintáctico convencional y aceptado y se impone la atonalidad -Schönberg-. ${ }^{3}$ Igualmente los títulos de las composiciones impiden cualquier relación con la realidad. También la crisis de los medios poéticos es un fenómeno reciente. A fines del XIX algunos poetas rompieron los límites tradicionales de la sintaxis y el sentido, caso de Rimbaud, Lautréamont o Mallarmé, que deseaban «restaurar en el lenguaje un estado fluido, provisional» y «devolver a la palabra el poder de encantamiento». ${ }^{4}$ Con ese fin, Rimbaud elimina la causalidad: en sus poemas en prosa las palabras no comunican sino sólo hacia adentro. Es una significación privada, difícil al lector corriente. Pero para Steiner son grandes genios los que hacen esto. Estas estrategias rupturistas se empequeñecerían en manos de poetas menores. La ruptura con la sintaxis y el significado se relaciona con el ideal musical, importantísimo en la literatura moderna. Recuérdese el simbolismo, que busca la sonoridad. Con la música, el poeta pretende escapar también de la linealidad, de la lógica, de la sintaxis, frente a lo que busca:

\footnotetext{
${ }^{2} I b .$, p. 39.

${ }^{3}$ Cfr. T.A. Adorno, Teoría estética, Barcelona, Orbis, 1983, p. 283.

${ }^{4}$ G. Steiner, op. cit., p. 46.
} 
la simultaneidad, la inmediatez, la libertad. Por eso el ideal máximo es el arte de la música desde la sensibilidad romántica, simbolista y moderna.

Estas ideas de Steiner pueden arrojar alguna luz sobre la cuestión del verso libre y sus juegos tipográficos. La disposición tipográfica que desvirtúa visualmente la del verso tradicional no es sino expresión, como ya se apuntó, de un nuevo modo de sentir que va contra el verso como orden convencional centralizador y objetivo y contra la sintaxis que corresponde también al mismo orden tradicional y centralizador. Se trata de una reivindicación del sujeto moderno desmembrado y en conflicto y de su modo particular de sentir la ausencia de un orden divino. La ruptura de la sintaxis se lleva hasta los límites con la ruptura visual y rítmica del verso: ahora es la palabra -no el verso ni la frase- la protagonista, la idea desnuda, palabras que aparecen aisladas sin conexión, en una percepción que las hace más independientes, más absolutas, más perceptibles, es decir, desautomatizadas.

La nueva forma, como indica Adorno, anuncia el cambio de la visión armónica del universo. En la modernidad «la verdad sobre la armonía es la disonancia». ${ }^{5}$ La liberación de la forma implica ir contra la sociedad, el status quo, contra la imagen del padre. El arte moderno es siempre revolucionario a través de una forma pura que adquiere un sentido subversivo. ${ }^{6}$

Todo tipo de experimentación que se asume bajo la etiqueta de verso libre ha tenido la función de ampliar y renovar, cuando no romper abiertamente, ciertas formas de la versificación tradicional. Si en algunos casos logra asentar y reafirmar composiciones de carácter regular no estróficas, como la silva, en otros, al otorgar una mayor importancia a los efectos visuales de la página, llega a destruir el verso. Independientemente de estas y otras consecuencias, el rasgo general que justifica y define el verso libre en sus diferentes manifestaciones históricas es su voluntad de ruptura con la tradición, propósito que no es exclusivo de la poesía, sino que caracteriza también a otros ámbitos

${ }^{5}$ T.A. Adorno, op. cit., p. 148.

${ }^{6}$ Véase $i b .$, p. 333. 
literarios y artísticos, sobre todo del siglo xx. Conviene recordar a este respecto que la poesía occidental del pasado siglo se ha visto afectada por una serie de movimientos estéticos que desconfian de moldes anteriores y tienden al experimentalismo. La culminación de estas tendencias, ya presentes de forma atenuada en el siglo XIX, se da definitivamente en las llamadas vanguardias históricas, que serán continuadas con períodos de mayor o menor intensidad a lo largo de todo el siglo xx. Los movimientos de vanguardia, en contra de toda convención, destruyen formas tradicionales preexistentes. Eso es lo que sucede también con el verso y sus elementos básicos y lo que lleva a la aparición del llamado verso libre.

En este sentido, ya Mallarmé, que había experimentado con el alejandrino y el verso liberado, había anunciado la necesidad de crear una forma nueva que no fuera ni verso ni prosa, sino la expresión absoluta de la música interior. Este deseo se resolvió en su Un coup de dés, antesala simbolista de las vanguardias europeas y de la poesía visual. La relación entre la interioridad subjetiva del poeta y los experimentalismos métricos es evidente en "La música y las letras" ("La Musique et les lettres"), de 1894, donde relaciona el verso libre con el desequilibrio espiritual del hombre moderno y la modulación rítmica personal, que ha encontrado en la nueva forma su plenitud expresiva: «Un hermoso hallazgo, con el que queda, poco más o menos, clausurada la búsqueda de ayer, lo tenemos en el verso libre, modulación (digo a menudo) individual, ya que toda alma es un nudo rítmico»? ${ }^{\text {? }}$

Octavio Paz, en Los signos en rotación, ${ }^{8}$ al referirse a la poesía moderna la explica, como Steiner, como la manifestación de una nueva visión artística. Para el saber antiguo la

${ }^{7}$ S. Mallarmé, Prosas, edición de J. del Prado, Madrid, Alfaguara, 1987, p. 211. Sobre la confusión verso y prosa en Mallarmé, vide M.V. Utrera Torremocha, Teoría del poema en prosa, Sevilla, Universidad de Sevilla, 1999, pp. 195 y ss. Cfr. W.Th. Elwert, "Mallarmé entre la tradition et le vers libre: Ce qu'en disent ses vers de circonstance", en M. Parent (ed.), Le vers français au XXe siècle, París, Klincksieck, 1967, pp. 123-138.

${ }^{8}$ Véase O. Paz, "Los signos en rotación", en Los signos en rotación y otros ensayos, Madrid, Alianza Tres, 1983, pp. 309-342. 
finalidad sería contemplar y representar la realidad; en el saber moderno de la técnica se pretende sustituir esa realidad por un universo de mecanismos; por ello las obras dejan de ser réplicas de un arquetipo, símbolos de mundo y del hombre para pasar a ser signos de acción y no imágenes de mundo: «La técnica libera a la imaginación de toda mitología y la enfrenta con lo desconocido. La enfrenta a sí misma y, ante la ausencia de toda imagen del mundo, la lleva a configurarse. Esa configuración es el poema».9 Se trata de un poema plantado sobre lo informe, es un espacio vacío, no es todavía presencia, sino un grupo de signos que buscan su significado y que significan sólo esa búsqueda. Eso sería Un coup de dés, de Mallarmé, obra que representa una clara bisagra que abre una nueva época y pretende crear un nuevo género con el apogeo de la página como espacio literario: «El poema cesa de ser una sucesión lineal y escapa así a la tiranía tipográfica que nos impone una visión longitudinal del mundo, como si las imágenes y las cosas se presentasen unas detrás de otras y no, según realmente ocurre, en momentos simultáneos» ${ }^{10} \mathrm{La}$ disposición tipográfica corresponde a una inspiración poética distinta y niega la posibilidad de decir algo absoluto sobre la realidad externa. Pero el espacio en la nueva poesía sería, además, extensión del ritmo del poema: «La página, que no es sino la representación del espacio real en donde se despliega la palabra, se convierte en una extensión animada, en perpetua comunicación con el ritmo del poema. Más que contener a la escritura se diría que ella misma tiende a ser escritura». ${ }^{11} \mathrm{La}$ tipografía se hace, pues, figura rítmica visual. Se trata de una relación, nueva en Occidente, de interpenetración entre página y escritura: el espacio se vuelve escritura, los espacios en blanco son silencios y significan. El juego espacial implica también la pluralidad y la simultaneidad. Todo es signo: las palabras y los blancos, buscando un significado ausente, de ahí la definición del poema como ideograma.

\footnotetext{
${ }^{9}$ Ib., p. 320.

${ }^{10}$ Ib., p. 327.

${ }^{11}$ Ib., p. 337.
} 
También Umberto Eco entiende el arte contemporáneo en relación con la ruptura del orden tradicional aparentemente eterno y que correspondería a una estructura objetiva e inmutable del mundo. ${ }^{12}$ Como explica a propósito de la música, la obra musical nueva, frente a la clásica de Bach, por ejemplo, no ofrece una forma cerrada que el ejecutor deba seguir, no se trata de un mensaje concluso, definido, organizado con un sentido único, sino de posibles organizaciones que dependen del intérprete, de ahí que sean obras no terminadas, abiertas..$^{13}$ Con la aproximación a la música -Verlaine- y la defensa de la oscuridad en favor de la sugestión -Mallarmé- se evita también en poesía dar un sentido único desde el principio: «El espacio en blanco en torno a la palabra, el juego tipográfico, la composición espacial del texto poético, contribuyen a dar un halo de indefinido al término, a preñarlo de mil sugerencias diversas». ${ }^{14}$ El poema nuevo estaría determinado entonces, como explicaba O. Paz, por la ausencia de un significado único, de ahí que Eco lo califique como un tipo de arte «en movimiento», abierto a varios sentidos y lecturas. Como ejemplo de obra literaria en movimiento propone Eco el Livre, de Mallarmé, la obra total que no llevó a término. Mallarmé quería hacer un libro dinámico, que ni comenzara ni terminara, móvil, como su Coup de dés. Ya en éste la gramática, la sintaxis y la disposición tipográfica introducen «una poliforme pluralidad de elementos en una relacion no determinada». ${ }^{15}$ En el Livre las páginas no seguirían un orden previsto sino que serían relacionables, permutables, sugerentes, abiertas, intercambiables. No hay significado discursivo lineal, frases y palabras aisladas sugieren y entran en relación con otras, dando lugar a nuevas formas de asociación sugestivas, sin sentido fijo. Ya no es posible la expresión, como en la obra antigua -medieval-, de una concepción del cosmos jerárquica, ordenada y monocéntrica, que se asienta «incluso en la misma

\footnotetext{
${ }^{12}$ Véase U. Eco, Obra abierta, Barcelona, Planeta-De Agostini, 1985, p. 46.

${ }^{13}$ Cfr. ib., pp. 64-65.

14 Ib., pp. 70-71.

$15 \mathrm{Ib}, \mathrm{p} .76$.
} 
férrea constricción interna de metros y rimas». ${ }^{16} \mathrm{La}$ presencia del subjetivismo hace que el protagonismo pase del ser a la apariencia. Importa entonces cómo se ve la realidad, y esto conduce a la entrada de lo indeterminado y lo ambiguo de cada percepción: «El verdadero contenido se convierte en su modo de ver el mundo y de juzgarlo, resuelto en modo de formar, y a ese nivel habrá que conducir el discurso en torno a las relaciones entre el arte y el mundo propio» porque «el arte conoce el mundo a través de las propias estructuras formativas» y «la obra literaria significa el mundo a través de la manera como se disponen estas palabras».$^{17}$

La reivindicación del ritmo personal y musical en la nueva poesía plantea, no obstante, un problema de tipo práctico: ¿cómo determinar la medida, ya que existe ritmo, de esos versos nuevos?; ¿se debe atender al patrón rítmico muchas veces implícito del verso tradicional?; en un verso dispuesto discontinuamente, ¿cómo ha de ser su lectura? En definitiva, ¿cómo entender el problema del ritmo de la poesía libre en la teoría del siglo xx? No hay que olvidar que partiendo de las primeras opiniones de los poetas, casi la totalidad de los críticos explica la aparición y desarrollo del verso libre como el resultado de la pura expresión del ritmo personal, del pensamiento y las emociones individuales. ${ }^{18}$

Ya los simbolistas, frente a un modelo rítmico preestablecido, que representa el verso, reivindican la preponderancia del ritmo interior en la creación poética. Gustave Kahn basa la unidad rítmica del verso en la unidad de sentido, de manera que el poeta

\footnotetext{
${ }^{16} \mathrm{Ib}$, p. 79.

${ }^{17} \mathrm{Ib} .$, p. 275.

${ }^{18}$ Cfr. V. Zirmunskij, Introduction to Metrics (1925), La Haya, Mouton, 1966, pp. 2627; P. Henríquez Ureña, "En busca del verso puro", Estudios de versificación española, Buenos Aires, Universidad de Buenos Aires-Instituto de Filología "Doctor Amado Alonso", 1961, p. 254; I. Paraíso, El verso libre hispánico. Orígenes y corrientes, Madrid, Gredos, 1985, p. 55; J. Domínguez Caparrós, Diccionario de métrica española, Madrid, Paraninfo, 1985, p. 179; C. Scott, Reading the Rhythm. The Poetics of French free Verse. 1910-1930, Oxford, Clarendon Press, 1993, p. 6; G.B. Cooper, Mysterious Music. Rhythm and free Verse, Stanford, Stanford University Press, 1998, pp. 30-35.
} 
libre se dejaría arrastrar por el sentido de la frase breve, producto del impulso interno. Así, la unidad del verso se define como «un fragment le plus court possible figurant un arrêt de voix et un arrêt de sens». ${ }^{19}$

Paul Claudel, sin dejar a un lado la idea del ritmo interior subjetivo, va más allá y define el verso tipográficamente como compuesto «d'une ligne et d'un blanc» ${ }^{20}$ lo que supone un todo lógico y un todo poético. Como Mallarmé, destaca la importancia de los blancos del poema, que, con su silencio, crean un ritmo especial. En este sentido, y ligado al concepto de verso, el verset o versículo sería, como expone en Réflexións et Propositions sur le vers français, "une idée isolée par du blanc». ${ }^{21}$ Los blancos serían, en última instancia, los que distinguirían la poesía de la prosa.

En el campo de los estudios métricos también se explica el verso libre como expresión del ritmo interior. En su estudio sobre Pablo Neruda, por ejemplo, Amado Alonso relaciona el ritmo interior del verso libre con la manifestación lineal de «las intuiciones que dan salida y forma al sentimiento». Se trata, en parte, de un ritmo regido por moldes sintácticos, pero unidos entre sí porque el impulso emocional los enlaza, como en una cadena. ${ }^{22}$

También para Tomás Navarro Tomás, para quien el único elemento tradicional que el versolibrismo admite es el ritmo, éste «se funda en la sucesión de los apoyos psicosemánticos que el poeta, intuitiva o intencionalmente, dispone como efecto de la armonía interior que le guía en la creación de su obra». ${ }^{23}$

${ }^{19}$ G. Kahn, "Préface sur le vers libre", en Premiers poèmes, París, Mercure de France, 1897, p. 26.

${ }^{20}$ P. Claudel, Positions et Propositions, t. I, París, NRF, 1928, p. 64. Véase S. Bernard,

Le poème en prose de Baudelaire jusqu'à nos jours, París, Nizet, 1959, p. 413; J.

Lefebvre, "Le Verset des Cinq Grandes Odes", en S. Villani (ed.), Paul Claudel:

Les Odes: Poesie, rhetorique, theologie, Woodbridge, Albion, 1994, pp. 119-146; Y.

Scalzitti, Le Verset claudelien: Une Étude du rythme (Tête d'or), París, Minard,

1966; H. Guillemin, Paul Claudel et son art d'écrire, París, Gallimard, 1955, pp. 45

y ss.; J. Cohen, Estructura del lenguaje poético, Madrid, Gredos, 1970, p. 54.

${ }^{21}$ P. Claudel, op. cit., p. 10.

${ }^{22}$ A. Alonso, Poesía y estilo de Pablo Neruda (1951), Barcelona, Edhasa, 1979, p. 88.

${ }^{23}$ T. Navarro Tomás, Métrica española, Barcelona, Labor, 1991, p. 454. 
Respecto a Vicente Aleixandre, Dámaso Alonso hace notar igualmente el «énfasis retórico» de su poesía versolibrista, que relaciona con las obsesiones oníricas y el ritmo interior. ${ }^{24} \mathrm{El}$ recurso a explicar la ametría versolibrista como resultado del ritmo personal es, como se ve, frecuente en los estudios métricos y se vincula igualmente al ritmo de pensamiento, marcado por la unidad sintáctica de cada verso, las repeticiones y el paralelismo además de otros elementos retóricos.

Desde este punto de vista habría que prescindir de los modelos métricos tradicionales para explicar el ritmo de la nueva poesía. En algunos casos es imposible; en otros, inevitable. Pero los juegos con la tipografía pueden confundir el oído. Andrés Sánchez Robayna tiene poemas en los que las palabras quedan destacadas por la disposición en la página, agrupándose en conjuntos breves de apariencia pseudoestrófica. Estos conjuntos completan un verso que aparece entonces diseminado en el poema, con un claro fin expresivo, que destaca una o varias palabras en cada segmentación:

retama
tú que
yaces sobre
páramos 11
de viento y
matas
y sol
lento 9
dime tu
solo
ápice 7
blanco
pico
de soledad $\quad 9$

${ }^{24}$ Cfr. D. Alonso, Poetas españoles contemporáneos, tercera edición aumentada, Madrid, Gredos, 1965, pp. 278 y 284-287. 
adamada

retama 7

Isabel Paraíso, en su amplia tipología sobre el verso libre, considera, en relación a la versificación que se basa en el ritmo de pensamiento, el verso de imágenes acumuladas o yuxtapuestas libre, en el que predominan las imágenes reiteradas $\mathrm{y}$, sobre todo, la metáfora, ${ }^{25}$ y que es frecuente en la vanguardia. Se caracteriza por prescindir del paralelismo sintáctico para dar el protagonismo a una "red de imágenes afectivamente equivalentes, que traducen un especial estado anímico del poeta». Este tipo de composiciones suele aparecer con una disposición tipográfica anómala, propia de los juegos vanguardistas, y tiende a eliminar cualquier rasgo métrico, por lo que habitualmente «su ritmo no radica en la forma versal». ${ }^{26}$ Supone, pues, un paso más extremo que el versículo whitmaniano en la efectiva destrucción del concepto de verso. ${ }^{27}$ El juego de las imágenes sería evidente, por ejemplo, en el siguiente fragmento del poema "Mar" de Gerardo Diego: ${ }^{28}$

Cuántas tardes viudas

arrastraron sus mantos sobre el mar

Pero ninguna

como tú

tarde grave

hermana mía

señorita de compañía

dolorosa como una

Aquel poema desplegó sus velas y escribió con la quilla sus estelas

versos horizontales

salpicados de acentos

que cantan sacudidos por los vientos

${ }^{25}$ Cfr. I. Paraíso, El verso libre..., p. 31 y La métrica española en su contexto románico, Madrid, Arco/Libros, 2000, p. 190.

${ }^{26}$ I. Paraíso, El verso libre..., p. 400. Véase La métrica española..., p. 207.

${ }^{27}$ Cfr. I. Paraíso, El verso libre..., p. 284.

${ }^{28}$ Véase I. Paraíso, La métrica española..., pp. 190 y 207. 
Obsérvese, sin embargo, que, aparte de la rima, hay también un claro ritmo endecasilábico, con versos de cinco sílabas -versos 3 y 6-, siete sílabas -versos $1,7,11$ y $12-$, nueve sílabas -verso $8-$ y once sílabas - versos 2, 9, 10 y $13-$. Por su parte, los versos 4 y 5 , de cuatro sílabas tomados separadamente, si se unen en la lectura forman un heptasílabo.

No sucede así evidentemente en otros poemas de Gerardo Diego, en los que está ausente el ritmo versal tradicional. Pero incluso cuando es así hay que preguntarse qué papel juegan rítmicamente hablando los blancos de la página y si es lícito medir los versos según el modelo rítmico tradicional. Independientemente de las dificultades que pueda plantear la escansión de los versos libres, es necesario un estudio métrico de los mismos, único modo de llegar a discernir si se trata o no de versos, sean cuales fueran sus componentes métricos. ${ }^{29}$ Estudiar el verso libre prescindiendo de la base del verso clásico es obviar una gran parte de la poesía versolibrista que se asienta en la tensión y continua confrontación con el verso tradicional.

Los poemas que en muchas ocasiones se han vinculado con el verso libre por tener un origen común en cuanto al deseo de liberación de las convenciones anteriores, caso por ejemplo del caligrama y formas afines, en las que lo visual es el elemento principal, sí han de quedar fuera del estudio métrico, pues en nada se relacionan con la noción de verso tradicional.

También José Domínguez Caparrós ha destacado que los elementos fónicos, las repeticiones sintácticas y semánticas son en el verso libre esenciales, a lo que añade el aspecto visual, señalando que en el verso libre «el elemento rítmico dominante es de índole sintáctica, semántica o visual», ${ }^{30}$ porque la forma de

${ }^{29}$ Cfr. E. Torre, El ritmo del verso (Estudios sobre el cómputo silábico y la distribución acentual, a la luz de la Métrica Comparada, en el verso español moderno), Murcia, Servicio de Publicaciones de la Universidad de Murcia, 1999, pp. 12-13. Véase también E. Torre, Métrica española comparada, Sevilla, Servicio de Publicaciones de la Universidad de Sevilla, 2000, p. 23; I. Tinianov, El problema de la lengua poética (1924), Buenos Aires, Siglo XXI, 1972, pp. 20-39; H. Morier, Le Rythme du vers libre symboliste, étudié chez Verhaeren, Henri de Régnier, Viélé-Griffin, et ses relations avec le sens, vol. I, Ginebra, Les Presses Académiques, 1943, p. 19.

30 J. Domínguez Caparrós, Métrica española, Madrid, Síntesis, 1993, p. 46. 
percepción visual es a veces la única garantía de la existencia del verso libre. En los casos arrítmicos más extremos sería la tipografía el único indicio que diferenciaría el verso libre de la prosa, convirtiéndose en el único signo de verso, en icono de puro valor simbólico si se tiene en cuenta la semiótica. Así, «el verso quiere hacerse una señal de la expresión poética, un "icono", es decir, un signo en el que la forma del verso ayuda a captar el tema o el tono poéticos», siendo éste producto del pensamiento, del ritmo propio y personal. La disposición tipográfica, resultado del ritmo personal de pensamiento, haría del verso libre verso y no prosa. ${ }^{31}$ En efecto, muchas veces una disposición tipográfica distinta de la de la prosa determina una lectura del texto como verso incluso cuando no hay elementos rítmicos tradicionales.

José Domínguez Caparrós ${ }^{32}$ ha señalado cómo ya los formalistas rusos habían llamado la atención sobre la mayor carga significativa que suponían los espacios en blanco de la página y los juegos tipográficos por ser precisamente una deformación del discurso habitual, recurso que ha de situarse, como hacen ver los autores formalistas, no tanto en el ámbito métrico sino en el estilístico. ${ }^{33}$ Para Tinianov, la grafía se convierte en un importante «signo del verso, del ritmo y consecuentemente también de la dinámica métrica, condición indispensable del ritmo». ${ }^{34} \mathrm{En}$ este sentido, destaca la importancia de la tipografía como signo

\footnotetext{
${ }^{31}$ Ib., p. 28. Véase J. Domínguez Caparrós, Diccionario de métrica española, p. 179; M.C. Bobes Naves, La semiología, Madrid, Síntesis, 1989, pp. 77-112.

${ }^{32}$ Véase J. Domínguez Caparrós, Métrica y poética. Bases para la fundamentación de la métrica en la teoría literaria moderna, Madrid, U.N.E.D., 1988, p. 53.

${ }^{33}$ Cfr. I. Tinianov, op. cit., pp. 73-75; B. Tomashevski, Teoría de la literatura, Madrid, Akal, 1982, pp. 98-100. En otros estudios generales de poesía o de métrica se concede también atención a la expresividad simbólica de estos juegos gráficos iniciados por Mallarmé en su Coup de dés (1898), además de otros autores ya mencionados. Véase J. Domínguez Caparrós, Diccionario de métrica española, p. 144, y Métrica española, pp. 240-242.; J. Cohen, op. cit., pp. 102-103; D. Alonso, op. cit., p. 236; M. Gasparov, Storia del verso europeo (1989), Bolonia, Il Mulino, 1993, pp. 311-314; J. de la Calle, "La métrica", en J.A. Hernández Guerrero (coord.), Manual de Teoría de la Literatura, Sevilla, Algaida, 1996, p. 231; R. Núñez Ramos, La poesía, Madrid, Síntesis, 1992, pp. 123-129; E. Torre, "El verso y sus elementos", en E. Torre y M.A. Vázquez, Fundamentos de Poética española, Sevilla, Alfar, 1986, p. 82.
}

${ }^{34}$ I. Tinianov, op. cit., p. 20. 
de un tipo de lectura que remite a una tradición métrica, la cual, aunque aparezca desarticulada, está, en realidad, siendo actualizada. Transcrito como prosa, el verso libre se recibirá por parte del lector de otra manera y poseerá, por tanto, otro significado. ${ }^{35}$ También Tomashevski hizo notar la importancia de la representación gráfica en el verso como signo de otra clase de ritmo diferente del ritmo prosístico, hecho en el que han insistido otros estudiosos, como J. Cohen, J. Domínguez Caparrós, B. Hrushovski, C. Scott, J. Filliolet, que habla de una poética del espacio, G.B. Cooper, etc. ${ }^{36}$ La importancia del blanco en la página que remite a la pausa versal ha sido destacada por Pedro Henríquez Ureña en "En busca del verso puro" como única marca rítmica que quedaría en el verso libre más vanguardista, que prescinde de cualquier factor rítmico tradicional. ${ }^{37}$ La unidad rítmica sería entonces el verso en sí, animado por un impulso sin apoyos rítmicos exteriores, que sería de carácter íntimo y espiritual, idea con la que vuelve Henríquez Ureña a caracterizar el verso libre partiendo de aspectos meramente subjetivos.

Ante esta problemática, como ha apuntado Lawder, ${ }^{38}$ el verso queda entonces definido no por el ritmo (metro y rima), sino por

${ }^{35} \mathrm{Ib}$., pp. 38-39.

${ }^{36}$ Vide B. Tomashevski, "Sobre el verso", (1927), en T. Todorov (ed.), Teoría de la literatura de los formalistas rusos (1965), México, Siglo XXI, 1970, p. 115; J. Domínguez Caparrós, Métrica y poética, pp. 21-24; B. Hrushovski, "On free Rhythms in modern Poetry", en Th.A. Sebeok (ed.), Sytle in Language, Cambridge (Mas.), The M.I.T. Press, 1960, pp. 185-186; C. Scott, A Question of Syllables. Essays in nineteenth Century French Verse, Cambridge, Cambridge University Press, 1986, pp. 181-195; J. Filliolet, "Problématique du vers libre", Language Français, 23 (1974), pp. 65-66; G.B. Cooper, op. cit., pp. 91-101; H. Meschonnic, Critique du rythme. Anthropologie historique du langage, Lagrasse, Verdier, 1982, p. 606; Ch.O. Hartman, Free Verse. An Essay on Prosody, Princeton, Princeton University Press, 1980, pp. 81-103; A. Kibédi-Varga, "Syntaxe et rythme chez quelques poètes contemporains", en M. Parent (ed.), op. cit., pp. 176-181; K. Spang, Análisis métrico, Pamplona, E.U.N.S.A., 1993, p. 62, y Ritmo y versificación. Teoría y práctica del análisis métrico y rítmico, Murcia, Universidad de Murcia, 1983, pp. 75-76, passim; F. López Estrada, Métrica española del siglo XX, Madrid, Gredos, 1969.

${ }^{37}$ Véase P. Henríquez Ureña, "En busca del verso puro", loc. cit., p. 255; P. Jauralde Pou, "Poesía española actual. La cuestión métrica", Voz y Letra. Revista de Literatura, X, 1 (1999), pp. 119-120.

${ }^{38}$ Véase B. Lawder, Vers le vers, París, Nizet, 1993, p. 58. 
la línea, la linéation. Dentro de los escasos estudios de conjunto dedicados en España al verso libre, Francisco López Estrada parte de la premisa del ritmo interior tanto en su Métrica española del siglo XX, de 1969, como en un artículo anterior titulado "La métrica nueva" (1967). En ambos estudios pretende desligar la nueva poesía, que él asocia especialmente a la vanguardia, de la métrica tradicional. ${ }^{39}$ Para la nueva poesía López Estrada prefiere la denominación de líneas poéticas, frente a la de verso libre, con el fin de desvincular esta manifestación de toda posible relación con el concepto de verso regular. Para él, la línea poética lleva la ametría a un grado mayor de libertad, aunque a veces puede coincidir con la organización de los versos comunes. En estos casos, López Estrada habla de verso semilibre, que aparecería, por ejemplo, en la silva en sus modalidades no clásicas. El paso del verso semilibre a la línea poética es sutil $\mathrm{y}$, desde luego, no son muy claras sus fronteras. ${ }^{40} \mathrm{La}$ intención de separar la línea poética -o verso libre- del verso regular lo lleva a utilizar términos diferentes de los de la métrica tradicional para referirse a aspectos que a todas luces son equivalentes, como, por ejemplo, cuando llama enlace al encabalgamiento. Pero la separación tajante de la línea respecto al verso es totalmente imposible desde el momento en que admite la mezcla efectiva de líneas y versos, así como la existencia del verso semilibre, que sería en ocasiones difícilmente distinguible de la línea poética. Especialmente contradictoria en su teoría es la aceptación de la libre combinación de versos y líneas. En este mismo sentido, resulta igualmente contradictorio el hecho de admitir que en una línea pueda haber varios versos identificables métricamente, como sucede, sobre todo, en los versos largos, aspecto que López Estrada no podía dejar a un lado tras los estudios que demostraban la tendencia al ritmo endecasilábico de Vicente Aleixandre, Luis Cernuda o Dámaso Alonso. ${ }^{41}$

${ }^{39}$ Cfr. F. López Estrada, "La métrica nueva", en VV.AA., Elementos formales en la lírica actual, Santander, U.I.M.P., 1967, pp. 104-105, y Métrica española del siglo $X X$, pp. 99-111 y $120-122$.

${ }^{40}$ Cfr. ib., pp. $158-160$.

${ }^{41}$ Vide ib., pp. 160-161. Cfr. C. Bousoño, La poesía de Vicente Aleixandre, segunda edición corregida y aumentada, Madrid, Gredos, 1968, passim; S. Fernández 
La insistencia en separar la línea poética tanto del verso como de la prosa tiene, no obstante, su razón de ser, ya que quiere destacar la profunda importancia que en la vanguardia adquiere el aspecto visual de la expresión poética, que afecta a buena parte de las manifestaciones literarias, incluido el verso. El ritmo visual es esencial en esta nueva poesía hecha para ser leída y a veces sólo para ser vista. Sólo así podrán entenderse los Caligramas de Apollinaire. ${ }^{42}$ Las novedades tipográficas, no exclusivas de la vanguardia y que no anulan siempre el concepto de verso, le permiten establecer una clasificación que puede resumirse en los siguientes tipos de líneas: 1) línea poética cerrada o versículo, en la que se da la esticomitia; 2) línea poética fluyente, con enlace -encabalgamiento-; 3) línea poética fragmentada, que aparece dividida en dos, con un blanco amplio en medio, y que, según Paraíso, sería la línea rota, dividida en partes por blancos; 4) línea poética diseminada, que, como explica Paraíso, es una modalidad más extrema, frecuente en los caligramas y los juegos ultraístas; 5) línea poética escalonada, que sería más bien una variante de la anterior; 6) línea complementaria, de la que bien podría prescindirse porque sólo se explica por la necesidad tipográfica de terminar un verso que no cabe en un único renglón; y 7) línea poética con sangría menor, media o mayor, que divide en dos la línea quedando su segunda parte sangrada. ${ }^{43}$ El criterio que anima estas clasificaciones es el visual. No por ello deja a un lado el criterio fónico, complementario del anterior. Líneas que aparecen divididas en dos renglones se toman y se miden como una sola unidad melódica que responde bien al pensamiento bien

Ramírez, "Forma y sustancia líricas", en VV.AA., Elementos formales en la lírica actual, ed. cit., pp. 45-54; R. Ballesteros, "Algunos recursos rítmicos de Hijos de la ira”, Cuadernos Hispanoamericanos, 215 (1967), pp. 371-380; M.J. Flys, La poesía existencial de Dámaso Alonso, Madrid, Gredos, 1968, passim.

${ }^{42}$ Cfr. F. López Estrada, op. cit., pp. 111-112.

${ }^{43}$ Véase F. López Estrada, ib., pp. 136-147, y art. cit., pp. 105-108. Cfr. I. Paraíso, El verso libre..., p. 50. A esta tipología basada en la tipografía de la línea, se añade la división entre poema simple, formado por la sucesión continuada de versos, y poema complejo, que presenta divisiones internas de distintos tipos y que responde a una ordenación pseudoestrófica. Véase. F. López Estrada, art. cit., p. 111, у op. cit., pp. 154-155. 
al sentimiento, es decir, al ritmo psíquico del contenido. ${ }^{44}$ Así, las líneas siguen manteniendo su unidad por más que puedan aparecer divididas de diversas maneras.

La clasificación versolibrista que hace Spang está basada fundamentalmente, como la de López Estrada, en criterios tipográficos, aunque tiene en cuenta también otros factores. ${ }^{45}$ Los espacios en blanco entre versos o dentro de un mismo verso suponen en la lectura silencios o pausas. Al lector corresponderá, de acuerdo con su capacidad interpretativa, discernir si la pausa en cuestión es o no versal, aunque lo más aconsejable es seguir el criterio de respetar los grupos sintácticos de significado completo. ${ }^{46}$ Como es apreciable, tanto López Estrada como K. Spang conceden a los juegos tipográficos una atención especial, sin por ello dejar de referirse a la presencia de un ritmo personal psicosemántico que animaría siempre el espíritu versolibrista.

Otros autores han dejado constancia de la necesidad de tener en cuenta la tipografía en el verso libre por suponer en el poema la entrada del ritmo visual de claro contenido simbólico. Así, en dos estudios sobre la poesía del 27, M.I. López Martínez ha demostrado cómo «la grafía puede proporcionar valores rítmicos que suponen repetición». Este ritmo visual se cumple perfectamente en el versolibrismo de vanguardia, en que la representación gráfica contribuye en ocasiones al ejercicio mimético y expresivo. En general, ideas, acciones o sentimientos como el vacío, el movimiento, la soledad, etc., quedarían potenciados por la tipografía. ${ }^{47}$

A. Luján Atienza se refiere también a los juegos tipográficos, destacando su interés por funcionar como marcas de verso y por su alto valor expresivo. Siguiendo a López Casanova expone algunos de los procedimientos tipográficos, desde la distribución

44 Vide F. López Estrada, art. cit., pp. 114-115, y op. cit., p. 133.

${ }^{45}$ Vide K. Spang, Ritmo y versificación, p. 88.

${ }^{46}$ Cfr. ib., p. 90, y Análisis métrico, pp. 75, 109-110 y 125-126.

47 Vide M.I. López Martínez, "Valores gráficos del verso libre en el grupo del 27 (I)", Anuario de Estudios Filológicos, XI (1988), pp. 231-251, y "Valores gráficos del verso libre en el grupo del 27 (II)", Anuario de Estudios Filológicos, XII (1989), pp. 145-170. Sobre el ritmo visual, cfr. O. Belic, Verso español y verso europeo. Introducción a la teoría del verso español en el contexto europeo, Santafé de Bogotá, Instituto Caro y Cuervo, 2000, pp. 558-565. 
gráfica habitual hasta el caligrama o el letrismo. ${ }^{48}$ Respecto a los mismos versos regulares a veces la forma -corta o larga, sirve para reforzar el significado, como ya vio López Martínez:

Y así voy, ciego y loco, por este mundo amargo;

a veces me parece que el camino es muy largo,

$\mathrm{y}$ a veces que es muy corto...

\section{RubÉN DaRío}

También puede tener un valor expresivo el uso de mayúsculas, tipo de letra, "faltas" de ortografía, la supresión de los signos de puntuación o el iconismo gráfico, destacado por otros autores y por el que el poema intenta representar casi pictóricamente aquello de lo que habla: ${ }^{49}$

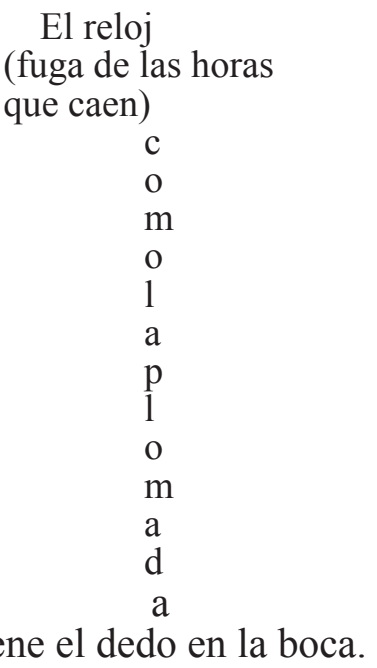

\section{Eliodoro Puche}

${ }^{48}$ Véase A.L. Luján Atienza, Cómo se comenta un poema, Madrid, Síntesis, 2000, pp. 221-224; A. López Casanova, El texto poético. Teoría y metodología, Salamanca, Ediciones del Colegio de España, 1994, pp. 134-142; C. Segre, Principios de análisis del texto literario, Barcelona, Crítica, 1985, pp. 63-68; J. Domínguez Caparrós, Introducción al comentario de textos, Madrid, Servicio de Publicaciones del Ministerio de Educación y Ciencia, 1982, pp. 38-39.

${ }^{49}$ Véase A. Luján Atienza, op. cit., pp. 224-225. 
En esta misma línea se manifiesta Pablo Jauralde. En un reciente trabajo concibe la poesía actual como distinta a la clásica por la importancia, entre otros factores, que concede la primera a los juegos tipográficos. ${ }^{50}$ Se produciría en ella una consciente confusión con otras formas artísticas, como la pintura o el dibujo, propia de la modernidad. Sin embargo, el poema de Javier Yagüe que Jauralde ofrece como ejemplo de esa clase de poesía moderna, que respondería, según él, a la ruptura con la métrica tradicional, tiene un considerable número de versos impares -heptasílabos y pentasílabos:

Humo

Fumo más cada día

para volverme humo

pero es

de una vez

$$
\text { y consumirme }
$$

\section{o bien}

me pongo a fuego lento

para que

a tu regreso

no me encuentres así

desvencijado

roto

y en mi lugar solo quede un charquito purísimo.

Según Jauralde, se trata de un poema «dispuesto en partitura», lo que permite al autor «desdeñar sin contemplaciones otras particularidades, como la de la rima, el isosilabismo e incluso el ritmo canónico»». ${ }^{51}$ Pero en la lectura es perceptible la presencia de versos endecasílabos y heptasílabos combinados en distintas líneas, cuya tipografía cumple, sin duda, una función expresiva. Véanse, por ejemplo, los dos endecasílabos resultantes de la unión de los versos 2 y 3 y 4 y 5 -«fumo más cada día pero es»

${ }^{50} C f r$. P. Jauralde Pou, art. cit., p. 111.

${ }^{51} \mathrm{Ib}$., p. 125. 
y «para volverme humo y consumirme»-, y los heptasílabos resultantes de la unión de los versos 6 y 7, 9 y 10 y 12 y 13 - «de una vez o bien», «para que a tu regreso», «desvencijado roto». Lo mismo sucede con otros poemas que juegan con la tipografía para lograr una mayor expresividad, pero que no desdeñan ciertas pautas rítmicas. En la siguiente composición de Jaime Siles, "Aire escrito. I", la disposición en escalera de algunas palabras no impide la lectura de las mismas como verso endecasílabo, precedido además por otros dos endecasílabos:

Alas que son materia si las miro.

Ondulación precisa, si las pienso.

Alas.

Gaviotas.

Picos.

Patas.

Plumas.

Aire escrito.

Materia en sucesión.

Cielo sonoro.

Signos

que un cuerpo mira

resbalar en ojos.

Los versos que siguen a la figura en escalera se rigen igualmente por el ritmo endecasilábico, formando un endecasílabo -«Aire escrito. Materia en sucesión»-, un heptasílabo -«Cielo sonoro. Signos»- y un endecasílabo - «que un cuerpo mira resbalar en ojos»)-.

En el trabajo titulado En busca del verso español, O. Belic, al referirse al verso libre, habla de una norma rítmica distinta de la que rige el ritmo del verso con medida silábica fija, ${ }^{52}$ pero finalmente, sin precisar esa norma, identifica el verso libre con la prosa y lo excluye del ámbito métrico para justificarlo sólo por la tipografía. Recientemente, en Verso español y verso europeo,

${ }^{52}$ Véase O. Belic, En busca del verso español, Praga, Univerzita Karlova, 1975, p. 17. 
retoma esta cuestión para afirmar que en el verso libre la norma rítmica es distinta y variable y da lugar a «una forma versal específica y autónoma», ${ }^{53}$ que con un minimum de elementos rítmicos logra una variabilidad máxima. Sin embargo, admite que, aparte del esquema entonacional, dado por la segmentación rítmico-melódica que se basa en la segmentación tipográfica, no se puede dar una norma de validez general. Es la segmentación específica del verso libre la que lo separaría finalmente de la prosa. ${ }^{54}$

Teniendo en cuenta la condición tipográfica del verso libre y su relación con el ritmo prosaico y no sólo con el versal, Belic concluye que el problema del verso libre «excede las posibilidades de un enfoque puramente métrico». Es necesario, por tanto, abordar el verso libre «desde el punto de vista estético». ${ }^{55} \mathrm{La}$ segmentación tipográfica tendría una importancia capital porque potenciaría un tipo de comunicación diferente del de la prosa, de ahí que el verso libre no sea «algo arbitrario y gratuito», sino una «forma específica de expresión literaria (poética), que tiene sus propias características y posibilidades». ${ }^{56}$ Mientras para algunos autores la tipografía es simplemente en el verso libre un recuerdo del verso regular, para otros supone una marca funcional que determina una lectura diferente de la prosa. En este sentido, Hrabák, que considera el verso libre y la prosa rítmica como formas intermedias entre verso regular y prosa, aduce, siguiendo a Tinianov, que el verso libre «exige un certain aspect graphique pour être perçu comme une forme du langage "en vers" $\gg .{ }^{57}$ Entre

${ }^{53}$ O. Belic, Verso español y..., p. 568.

${ }^{54} C f$ r. ib., pp. 569 y 596.

${ }^{55} \mathrm{O}$. Belic, En busca del verso español, pp. 17-18. Véase O. Belic, Verso español y..., pp. 586-589.

${ }_{57}^{56}$ O. Belic, En busca del verso español, p. 20.

${ }^{57}$ J. Hrabák, "Remarques sur les corrélations entre le vers et la prose, surtout sur les soi-disant formes de transition", en VV.AA., Poetics, Poetyka, POETNKA. International Conference of Work-in-Progress Devoted to Problems of Poetics (Varsovia, August 18-27, 1960), Mouton, Panstwowe Wydawnictwo Naukowe-Varsovia, 'SGravenhague, 1961, p. 245. Cfr. En el marco de la semiótica literaria la disposición tipográfica del verso se convierte, asimismo, en señal que predispone a una determinada lectura. Cfr. M.C. Bobes Naves, op. cit., pp. 108-110; J. Culler, La poética estructuralista. El estructuralismo, la lingüística y el estudio de la 
los poetas, Jorge Luis Borges, por ejemplo, afirma en el prólogo a Elogio de la sombra que la consideración del verso libre como simple prosa con la apariencia tipográfica del verso es un planteamiento completamente erróneo, ya que la tipografía dispone al lector a un tipo de comunicación radicalmente distinta: «Es común afirmar que el verso libre no es otra cosa que un simulacro tipográfico; pienso que en esa afirmación acecha un error. Más allá de su ritmo, la forma tipográfica del versículo sirve para anunciar al lector que la emoción poética, no la información o el razonamiento, es lo que está esperándolo».$^{58}$

Como convención habitual del verso, la disposición tipográfica es un indicador decisivo para una clase de recepción. T.A. Van Dijk ha señalado la importancia que tiene en el contexto literario el conocimiento de los sistemas de reglas y convenciones tanto por parte del hablante como del oyente. ${ }^{59}$ La aceptación de un texto como literatura dependerá, pues, de normas y valores estéticos convencionales. La tipografía en el verso libre, en consecuencia, aun no siendo un factor métrico intrínseco, puede tomarse claramente como un indicador pragmático. Ya Mukarovsky había señalado que la obra de arte como artefacto se convertía en un objeto estético en virtud de su existencia dentro de una colectividad y de una estructura estética. El paso del artefacto al objeto estético se produce al situar la obra en la tradición y evolución literarias, teniendo en cuenta el sistema de normas de cada época. Es indudable que la valoración estética del artefacto dependerá estrechamente del «mundo histórico en que se produce la concretización». ${ }^{60}$

literatura (1975), Barcelona, Anagrama, 1978, pp. 194-195; I.M. Lotman, Estructura del texto artístico (1970), Madrid, Istmo, 1988, pp. 131-135 y 225.

58 J.L. Borges, Obra poética. 1923/1985, Buenos Aires, Emecé Editores, 1989, p. 317.

${ }^{59}$ Véase T.A. Van Dijk, "La pragmática de la comunicación literaria” (1977), en J.A. Mayoral (comp.), Estética de la recepción, Madrid, Arco/Libros, 1987, pp. 193194.

${ }^{60}$ L.A. Acosta Gómez, El lector y la obra. Teoría de la recepción literaria, Madrid, Gredos, 1989, pp. 105-107. Cfr. J. Mukarovsky, Escritos de estética y semiótica del arte, Barcelona, Gustavo Gili, 1977. 
Respecto al verso libre, es determinante, sin duda, el contexto histórico en que surge para comprender su aceptación y recepción como verso por parte de ciertos lectores. En este sentido, conviene tener en cuenta la concepción de la obra literaria como fenómeno histórico y la noción fundamental del horizonte de expectativas, según la teoría y estética de la recepción. El nacimiento y la recepción del texto literario aparecen en un determinado contexto y horizonte históricos que comparten el autor y los lectores. El horizonte de expectativas del lector se formará a partir de su propia experiencia vital, aunque es determinante, sobre todo, la tradición literaria recibida, que lo une a otros lectores en la identificación de las formas literarias. Sin embargo, el lector puede ampliar y variar este horizonte. Como sucede a veces con las innovaciones literarias, y es el caso del versolibrismo, puede ocurrir que no todos los lectores tengan el mismo horizonte estético-literario, de ahí las reacciones de aceptación y de rechazo. Las diferentes opiniones sobre el verso libre y su consideración como verso o prosa dependen, pues, de los lectores y de sus expectativas. ${ }^{61}$ Es evidente que la tipografía, en principio, favorece una determinada lectura; pero, una vez cumplida ésta, el lector confirmará o no las expectivas creadas gracias a la presencia o ausencia en el texto poético de los elementos métricos objetivos. De las reacciones del público y de las opiniones de la crítica dependerá la distancia estética existente entre el horizonte de expectativas dado en la tradición y el nuevo horizonte que abre la obra innovadora. ${ }^{62}$ El verso libre

${ }^{61}$ Cfr. H.R. Jauss, La literatura como provocación (1974), Barcelona, Península, 1976, pp. 163-164; L.A. Acosta Gómez, op. cit., pp. 70-75.

62 «Denominamos distancia estética a la distancia existente entre el previo horizonte de expectación y la aparición de una nueva obra cuya aceptación puede tener como consecuencia un "cambio de horizonte" debido a la negación de experiencias familiares o por la concienciación de experiencias expresadas por primera vez» (H.R. Jauss, op. cit., p. 174). Véase también A. Rothe, "El papel del lector en la crítica alemana contemporánea" (1978), en J.A. Mayoral (comp.), op. cit., p. 17. La relación de estas ideas con las del formalismo ruso ha sido indicada por Peter Bürger, quien critica el concepto de evolución literaria como simple sustitución de sistemas. En este sentido, señala: «Las tesis de la estética de la recepción pueden ser comprendidas como reformulación de la teoría de la evolución de los formalistas rusos desde un punto de vista hermenéutico. $\mathrm{Si}$, siguiendo a 
en un horizonte de expectativas determinado se entendería, por tanto, como verso siempre que el lector vea en la tipografía segmentada una marca de versalidad suficiente. Para otro tipo de lectores con un horizonte de expectativas más "conservador" son necesarios, además, otros rasgos versales, verdaderamente objetivos y esenciales al concepto de verso, que forman parte de la tradición.

El verso libre es resultado, pues, de una cultura y un pensamiento históricos, de ahí su naturaleza estética, como el de otras formas limítrofes entre prosa y verso, difíciles de definir desde uno u otro ámbito, y en las que es fundamental la tipografía. Recibido como verso únicamente por la disposición tipográfica, es, desde el estricto punto de vista métrico, prosa. Sólo sería estéticamente válido, como ha apuntado Belic, «cuando ofrece [...] más información, o tal vez mejor, una información distinta, de la que ofrecerían las mismas palabras transcritas mecánicamente en prosa». ${ }^{63}$

Tynjanov, la evolución literaria se opera de manera tal que los modos de proceder automatizados (es decir, que ya no son percibidos como recursos artísticos) son sustituidos por otros nuevos, Jauss considera que el horizonte de expectativas del público, determinado por el conocimiento previo del género así como por forma y temática de obras ya conocidas, sufre una decepción con la nueva obra, hecho que, simultáneamente, hace que se origine un nuevo horizonte de expectativas. De esta manera, Jauss concibe la evolución literaria como proceso inmanente de sustitución de un horizonte de expectativas por otro») (P. Bürger, "Problemas de investigación de la recepción” (1977), en J.A. Mayoral (comp.), ib., pp. 193-194). Claro que, como señala Bürger, esta concepción se daría en el momento histórico literario del siglo XIX a la vanguardia.

${ }^{63}$ O. Belic, En busca del verso español, p. 18. Cfr. O. Belic, Verso español y..., pp. 585-586. 
